\title{
Modification of the Development of Children's Fitness Cards and Fitness Love Board for Down Syndrome School-Age Children in the Fit 5 Special Olympics Progam
}

\author{
Yohanes Giovani Pion Makung ${ }^{1}$, Gigih Siantoro $^{2}$, Abdul Rachman Syam Tuasikal ${ }^{3}$ \\ ${ }^{1,2,3}$ Postgraduate Program in Sport Education Department, Universitas Negeri Surabaya, Indonesia \\ myohanes2014@gmail.com
}

\begin{abstract}
From the lock down condition, Down Syndrome children who are used to activities at school become lazy to do fitness exercises at home, while parents also increase their activities by accompanying their children while at home from morning to night. For this reason, it is necessary to provide a home fitness training program for Down Syndrome children by doing the Fit 5 Special Olympics program. And it is necessary to make a Fitness card and a fitness love board so that children with Down syndrome are more excited. The purpose of this study is to establish cooperation between physical education teachers and parents in maintaining the fitness of Down Syndrome children while at home, and to help maintain the fitness of Down Syndrome children during the lock down period this year and in the coming years if there is a lock down period. again. The subjects of this study were 3 Down syndrome students from Special Olympics Surabaya. The design of this research is development research with research instruments in the form of validation sheets and video recordings that will be used to draw descriptive conclusions. The data analysis technique used is descriptive. Product trial validation was carried out by 6 experts who have experience in treating children with Down syndrome and 3 parents of students. The results showed that the average validation score of the experts was $98 \%$ and the average validation score of the parents was $98 \%$ which was in the very good category. And it was concluded that the fit card and the love child fit board are fit for mass production. Suggestion for all of us is never to force a Down syndrome child to be willing to follow fitness movements according to our wishes, but let them do it themselves according to their own abilities.
\end{abstract}

Keywords down syndrome; fit 5 special olympics; physical fitness

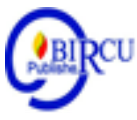

\section{Introduction}

Education is one aspect that is very important and a priority in the life of every human being. With good education, it will certainly give birth to future generations of the nation who are intelligent and competent in their fields. According to Sugiharto (2020) education is one of the efforts to improve the ability of human intelligence. So, to create the highest quality of human resources, education is becoming an important factor to be considered. Every country must provide the best policy for its people in getting education. One example is the Indonesian state which provides policies to the community, especially for children with special needs and is protected in the Regulation of the Minister of Women's Empowerment and Child Protection number 4 of 2017 with the consideration that every child with disabilities has the right to grow and develop, is entitled to protection 
from violence and discrimination and there are still many children with disabilities who have not been able to get the services they need and enjoy their rights because the infrastructure for them has not been properly fulfilled. Furthermore, in article 125 of Law Number 8 of 2016 concerning Persons with Disabilities it is explained that the obligation of the government and local governments is to provide information service units and fast action for services and protection for children with disabilities.

The state also guarantees education for children with disabilities as stipulated in the 1945 Constitution Article 31 Paragraph 1 which states that "Every citizen has the right to education". In the 1945 Constitution Article 31 paragraph 1 it is clear that all citizens have the right to education. Even citizens with physical and emotional limitations are entitled to education.

In providing educational services for citizens who have physical and emotional limitations, the state issues a policy in the form of a regulation of the Minister of National Education (Permendiknas) number 70 of 2009 article 4 paragraph 1 which states that "District / city governments appoint at least 1 (one) primary school. 1 (one) junior high school and 1 (one) senior high school in each sub-district are required to provide inclusive education and accept students with special needs.

All teachers want to provide the best educational services for all their students, even for children with special needs. But everything fell apart when the Corona virus first broke out in the Chinese city of Wuhan in January 2020, until it spread throughout the world to spread to Indonesia. Because the Corona virus does not mean that educational services must be stopped, it must be implemented even if students are at home, by way of School from Home (SFH). With this coronavirus outbreak, the government finally issued a LargeScale Social Restriction (PSBB) regulation in accordance with Minister of Health regulation number 9 of 2020, where the Minister of Health Regulation contains PSBB which covers restrictions on a number of certain population activities in an area suspected of being infected with COVID-19. Wahid (2020) stated that Covid-19 has bridged the rapidly increasing use of social media / internet, the existence of a distance learning system (online). Where these restrictions include school and work holidays, restrictions on religious activities, restrictions on activities in public places or facilities, restrictions on socio-cultural activities, restrictions on transportation modes, and restrictions on other activities specifically related to defense and security aspects.

At present, all countries in the world are facing a national health emergency because of the Covid-19 (Corona Virus) pandemic (C. Reotutar, 2020). From this PSBB condition, Down Syndrome children who are accustomed to activities at school become lazy to do fitness exercises at home because they are used to doing fitness exercises while at school. Meanwhile, parents also increase their activities by accompanying their children who have Down Syndrome while at home from morning to night. For this reason, it is necessary to provide a home fitness training program for Down Syndrome children by doing the Fit 5 Special Olympics program. And it is necessary to make a child fitness card that is carried by the parents as a reminder for the parents of the children's fitness training program at home, and it is necessary to make a love board for children to be fit as a reminder and a bait for Down Syndrome children so that they are enthusiastic in doing fitness exercises while at home. The purpose of providing the Fit 5 Special Olympics program is to establish collaboration between PJOK teachers and parents in maintaining the fitness of Down Syndrome children while at home, and parents know that the Fit 5 Special Olympics program can help maintain the fitness of Down Syndrome children during the PSBB period. This year and the year to come if there is another PSBB period. 


\section{Research Methods}

In this study, researchers used a research and development method design. According to Borg and Gall (1998) in Sugiyono (2019: 28), states that "research and development is a process / method used to validate and develop a product".

Meanwhile, according to Richey and Kelin (2010) in Sugiyono (2019: 29), states that "development research is a systematic study in designing a product, developing / producing the design, and evaluating the product's performance with the aim of obtaining empirical data to make a product. which can be used in learning or non-learning ".

From the source www.eric.ed.go in Sugiyono (2017: 30) states that "development research is a systematic way used to make designs, develop learning programs and products that can meet internal criteria".

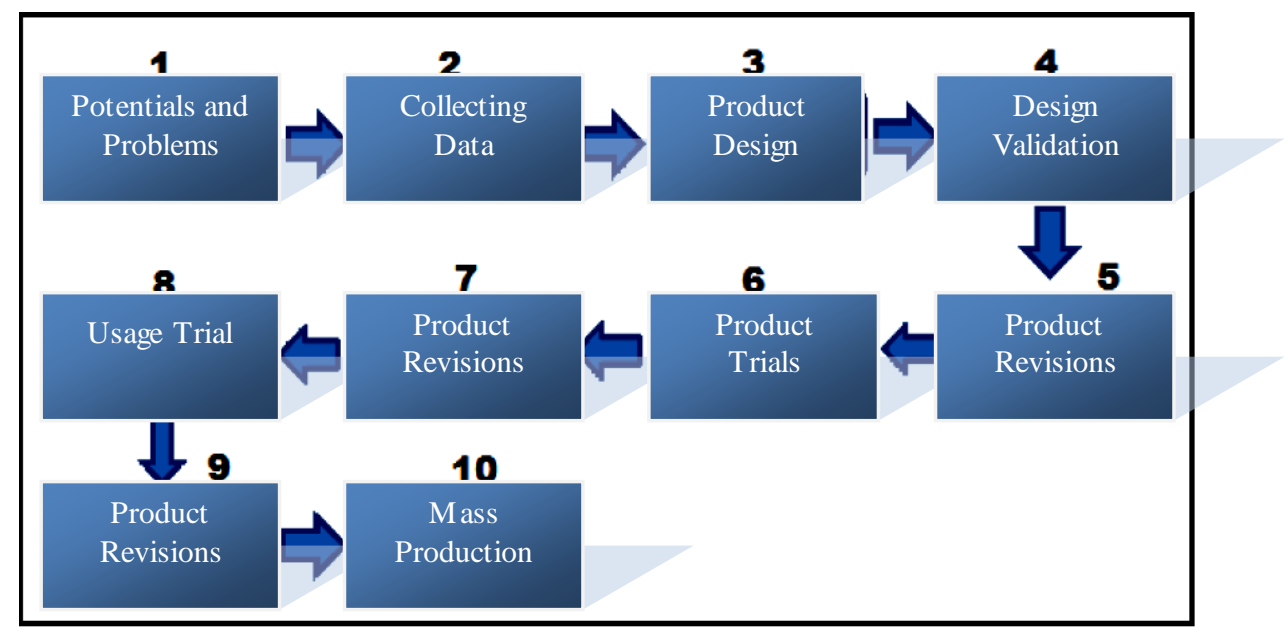

Figure 1. Ten Steps of Development Research According to Borg and Gall (1989) In Sugiyono (2019: 35)

The steps taken in conducting research are as follows:

1. Collecting information including analysis of integrity, review of literature by conducting interviews with several experts who are experienced in dealing with children with Down Syndrome, namely sports practitioners with special needs and special education.

2. collect data by conducting interviews and observing the condition of the parents, the condition of the child, the economic condition of the parents and the schedule of the child's daily activities. So that researchers can easily make fitness cards and love boards for children in shape.

3. After we have made observations and interviews, the next step is for the researcher to design the Fit 5 Guide Special Olympics modification for 2020, designing a fitness card that parents will carry as a tool to record children's fitness training activities and children's nutrition. After that, designing the love board for children to be fit, where every child after doing the exercise fills in the love board for children to be fit as a result of their fitness training.

4. After the design of the Fit 5 Guide Special Olympics modifiksai product in 2020 and the manufacture of fitness cards and the love board for fit children is complete, the product is evaluated by experts, namely sports practitioners, PLB teachers and the chairman of SOINA Jatim, where they have long experience handling Down children Syndrome. 
5. The design revision at this stage is to revise the 2020 Fit 5 Guide Special Olympics modification, making fitness cards and fitness children's love boards. After being validated by experts, then the modified Fit 5 Guide Special Olympics 2020 program was remade, a fitness card and a love fit child board that had been validated.

6. After revising the design, the results of the 2020 Special Olympics Fit 5 Guide modifications, the fitness card and the fitness card that had been revised in the design, were tested on a small scale (using a small sample) in collaboration with the Special Olympics Indonesia Provincial Administrators East Java. Where the sample does fitness exercises on Monday, Wednesday and Friday. Follow the movements and point at the video. After doing 1 fitness movement, the parents record the results achieved by the child on the fitness card while the child puts a fit pin on the love board for the fit child.

7. After conducting a small-scale trial, the researchers asked the help of experts to evaluate the results of the 2020 Special Olympics Fit 5 Guide modifiksai trial, fitness cards and small-scale fitness children's love boards.

8. After revising products that have been tested on a small scale, the results of the 2020 Fit 5 Guide Special Olympics modification, fitness cards and the love board for fit children will be tested on a large scale in collaboration with SOINA East Java.

9. After testing on a large scale, the researchers asked the help of experts to evaluate the results of the 2020 Special Olympics Fit 5 Guide modification, fitness cards and fitness children's love boards so that they can be more perfect before they are mass produced.

10. After revisions, the Fit 5 Guide Special Olympics modification products in 2020, fitness love cards and fitness love boards are ready for mass production through SOINA Jatim, K3S Kota Surabaya, MGMP PJOK Surabaya City.

The 10 steps, the researcher only took steps 1 to step 7 and then mass-produced the results of the product trial because the products produced could be mass produced after being tested on a small scale.

The subjects of this study were school-age Down Syndrome children under SOINA, East Java. According to Sriundy M. I Made (2015: 222) states that "the main requirement of a sample is that the sample taken from a population must truly represent the population or meet representative requirements. If the population is homogeneous, the size of the sample does not matter ". Of the homogeneous population types, no matter how many samples are taken, it will not affect the significance of the research results (Sriundy M. I Made, 2015: 222). For this reason, the researchers took 3 school-aged Down Syndrome children by drawing them to be used as small-scale trial samples, given the limited funds and time from the researchers.

The instrument in this study was an observation sheet on the condition of parents and children with Down Syndrome, a schedule for the daily activities of Down Syndrome children, interview sheets with parents and experts, video recordings of Down Syndrome parents and children activities, validation video recordings and revisions of the expert. All of these instruments are used to conclude the research results descriptively.

The analysis technique used is adjusted to the type of instrument being collected. This data analysis used descriptive analysis techniques and reflective analysis by examining the results of the preliminary study questionnaires and product validation questionnaires. The data obtained through questionnaires with descriptive analysis will be described in a narrative manner, while the data obtained through questionnaires with reflective analysis will be processed using percentage descriptive techniques. Types of data obtained from the results of feasibility tests (validation) by experts and trials by Down Syndrome children, namely quantitative and qualitative data. Qualitative data in the form of comments and 
suggestions on the trial questionnaire sheet. Meanwhile, quantitative data is in the form of numbers, namely $1,2,3,4$, and 5 based on a Likert scale which is then averaged and presented. Then the results of the final product were tested more widely in Down Syndrome children with processed data in the form of percentage results.

The data analysis technique used to analyze the data from the feasibility assessment is descriptive analysis technique. The percentage descriptive technique that will be used can be written as follows:

$$
\begin{aligned}
& \text { Percentage }=\frac{\left.\sum \text { (answer } \mathrm{x} \text { the weight of each option }\right)}{\mathrm{n} \times \text { highest weight }} \times 100 \% \\
& \text { Information: } \\
& \Sigma: \quad \text { Total } \\
& \mathrm{n}: \quad \text { Total Number of Questionnaire }
\end{aligned}
$$

The qualification levels of the eligibility criteria for concluding the validation results are as follows:

Table 1. Achievement Level Conversion

\begin{tabular}{|c|c|c|}
\hline Achievement Level & Qualification & Information \\
\hline $90-100 \%$ & Very Good & Do not be revised \\
\hline $75-89 \%$ & Good & Do not be revised \\
\hline $65-74 \%$ & Pretty Good & Revised \\
\hline $55-64 \%$ & Deficient & Revised \\
\hline $0 \%-54 \%$ & Not Good & Revised \\
\hline
\end{tabular}

(Sourced by Sudjana, 2005:35)

\section{Discussion}

The following are the results of research using research and development methods

\subsection{Product Design \\ a. Fitness Card}

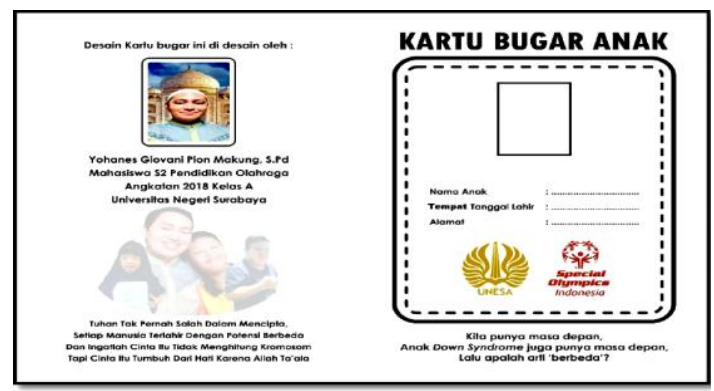

Figure 2. Front View Child Fitness Card https//tinyurl.com/UPLOAD-KARTU-BUGAR 


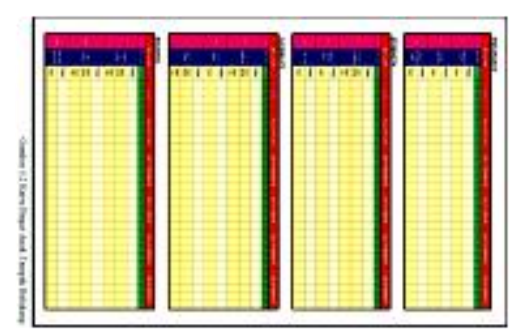

Figure 3. Back View Child Fitness Card

https:/tinyurl.com/UPLOAD-KARTU-BUGAR-BELAKANG

\section{b. Child Fitness Love Board and Pins}

This board is designed by the author to make Down Syndrome children interested and to make them enthusiastic about doing fitness exercises. This Love Fitness Child Board is made of metal coated board and covered with a banner on top. With the following design forms:

\section{https://tinyurl.com/UPLOAD-PAPAN-BUGAR}

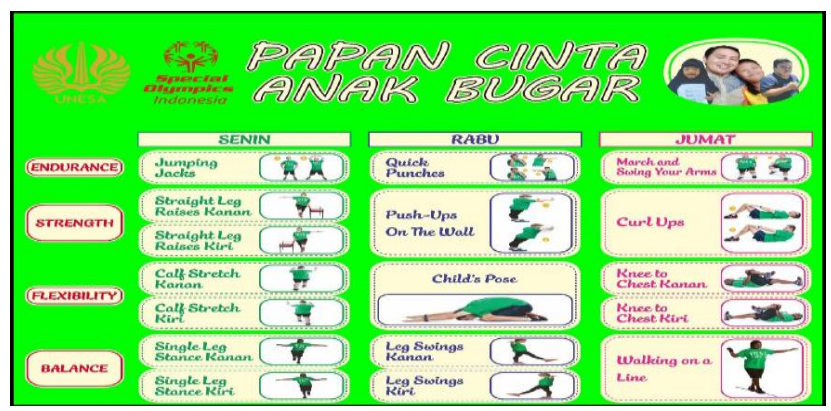

Figure 4. Love Board and Pins

In addition to the board, the author also made a fit pin from carom seeds that had been given a sticker with a fitness training image and had been given a small magnet so that it could be attached to the board, the pin has also been given the same image according to the Love Board for Healthy Children so that it helps children with Down Syndrome make it easier remember and paste the pins according to the movements that have been made. The pin design is as follows:

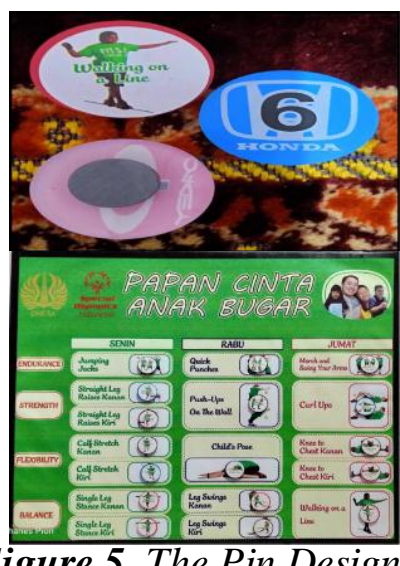

Figure 5. The Pin Design

https://tinyurl.com/UPLOAD-PAPAN-BUGAR-DAN-PIN 


\section{c. Fitness Video}

The video made by the researchers is a video from the Fit 5 Special Olympic program that has been modified to make it easier for children with Down syndrome to do fitness exercises. The results of the fitness video can be downloaded at:

Table 2. The Results of the Fitness Video

\begin{tabular}{|c|l|}
\hline Video & \multicolumn{1}{c|}{ Link } \\
\hline Day-1 & $\underline{\underline{\text { https://tinyurl.com/VIDEO- }}}$ \\
\hline KEBUGARAN-HARI-1 \\
\hline Day-2 & $\underline{\underline{\text { https:/tinyurl.com/VIDEO- }}}$ \\
\hline KEBUGARAN-HARI-2 \\
\hline Day-3 & $\underline{\text { https://tinyurl.com/VIDEO- }}$ \\
\hline
\end{tabular}

\section{d. Product Design Validation}

The validation was carried out by 6 experts who have long experience in the world of Down syndrome, including a Down syndrome sports coach, a special school teacher and the head of SOINA, East Java. The results of product design validation by experts are as follows:

Table 3. The Results of Product Design Validation

\begin{tabular}{|c|l|c|c|c|l|}
\hline No & \multicolumn{1}{|c|}{ Name } & Score & $\begin{array}{c}\text { Percentage } \\
\text { Score }\end{array}$ & Qualification & \multicolumn{1}{|c|}{ Information } \\
\hline 1 & Farida Martarina & 92 & $92 \%$ & Very Good & $\begin{array}{l}\text { Worth Testing, } \\
\text { Do not be revised }\end{array}$ \\
\hline 2 & Iska Putranto Ssaptadi, S.Pd & 91 & $91 \%$ & Very Good & $\begin{array}{l}\text { Worth Testing, } \\
\text { Do not be revised }\end{array}$ \\
\hline 3 & $\begin{array}{l}\text { Drs. Frans Marie Soepadi, } \\
\text { M.M }\end{array}$ & 85 & $85 \%$ & Good & $\begin{array}{l}\text { Worth Testing, } \\
\text { Do not be revised }\end{array}$ \\
\hline 4 & Mudah, S.Pd. M.Pd & 91 & $91 \%$ & Very Good & $\begin{array}{l}\text { Worth Testing, } \\
\text { Do not be revised }\end{array}$ \\
\hline 5 & Boentoro BS. S.Pd & 99 & $99 \%$ & Very Good & $\begin{array}{l}\text { Worth Testing, } \\
\text { Do not be revised }\end{array}$ \\
\hline 6 & Drs. Budi Haryono & 100 & $100 \%$ & Very Good & $\begin{array}{l}\text { Worth Testing, } \\
\text { Do not be revised }\end{array}$ \\
\hline & TOTAL A VERAGE & $\mathbf{9 3}$ & $\mathbf{9 3 \%}$ & Very Good & $\begin{array}{l}\text { Worth Testing, } \\
\text { Do not be revised }\end{array}$ \\
\hline
\end{tabular}

(Sourced by Sudjana, 2005:36)

From table 3 above, we can conclude that the product designs that have been made by the author get a very good average score so that the product design made by the author is worthy of being tested and does not need to be revised.

\section{e. Product Trial}

One week after introducing the products of Kartu Bugar Anak and Papan Cinta Anak Bugar to parents of students, then the research was carried out. This research was conducted 3 times a week, namely on Monday, Wednesday and Friday. Here the researchers modified the reduction of days in the Fit Five Special Olympics program, which should be 5 days a week to 3 days so as not to make Down Syndrome children feel bored so they don't want to do fitness exercises. 
On Monday, Down Syndrome children do fitness exercises in the form of:

1. Endurance (Jumping Jacks).

2. Strength (Right and Left Straight Leg Raises).

3.Flexibility (Right and Left Calf Stretch)

4. Balance (Right and Left Single Leg Stance)

The four items of fitness movements above are carried out following a fitness video that has been designed by the researcher with a duration of each movement of 30 seconds, the child does the movement as best he can and is not forced and does not have to be exactly the same as in the video.

After doing a fitness movement, the child can rest for a while while the parent directs the child to attach a fit pin according to the movement that has been done on the Cinta Anak Bugar board while the parent records the results of the number of times the child makes movements on the fitness card.

On Wednesday, Down Syndrome children do fitness exercises in the form of:

1. Endurance (Quick Punches).

2. Strength (Push Up On The Wall).

3.Flexibility (Children's Pose)

4. Balance (Right and Left Leg Swings)

By doing the fitness movement for 30 seconds the same as Monday, and pinning the love board for kids to be fit after each fitness move.

On Friday, Down Syndrome children do fitness exercises in the form of:

1. Endurance (March and Swing Your Arms).

2. Strength (Curl Ups).

3.Flexibility (Knee to Chest Right and Left)

4. Balance (Walking on A Line Right and Left)

By doing a fitness move for 30 seconds the same as Wednesday, and pinning the love board for kids to be fit after each fitness move.

\section{f. Product Validation By Parents}

After conducting the research, parents are also given a validation sheet to fill in and given a value whether the product test is feasible for mass production or not. With the results of the product test recap by parents as follows:

Table 4. The Results of Product Design Validation by Parents

\begin{tabular}{|c|l|c|c|c|l|}
\hline No & \multicolumn{1}{|c|}{ Name } & Score & $\begin{array}{c}\text { Percentage } \\
\text { Score }\end{array}$ & Qualification & \multicolumn{1}{|c|}{ Information } \\
\hline 1 & Ratna Wati, S.H, M.H & 98 & $92 \%$ & Very Good & $\begin{array}{l}\text { Worth Mass Production, } \\
\text { Do not be revised }\end{array}$ \\
\hline 2 & Rumanah & 100 & $100 \%$ & Very Good & $\begin{array}{l}\text { Worth Mass Production, } \\
\text { Do not be revised }\end{array}$ \\
\hline 3 & Sulistyorini, S.Pd & 96 & $96 \%$ & Good & $\begin{array}{l}\text { Worth Mass Production, } \\
\text { Do not be revised }\end{array}$ \\
\hline \multicolumn{2}{|c|}{ TOTAL AVERAGE } & $\mathbf{9 8}$ & $\mathbf{9 8 \%}$ & Very Good & $\begin{array}{l}\text { Worth Mass Production, } \\
\text { Do not be revised }\end{array}$ \\
\hline
\end{tabular}

(Sourced by Sudjana, 2005:37)

From table 4 above, we can see that the results of the product test validation recap by parents obtained a total average value of 98 with a percentage of $98 \%$ and the 
qualifications are very good so that it can be concluded that from the parents' point of view the product test results are suitable for mass production and do not need there is a revision.

\section{g. Product Validation by Experts}

After conducting product trials 3 times a week, the six experts were given video recordings of the first, second and third days of all research samples in conducting research. And then the six experts filled out the product test validation sheet, with the results of the product test recap as follows:

Table 5. The Results of Expert Product Test Validation Recap

\begin{tabular}{|c|c|c|c|c|c|}
\hline No & Name & Score & $\begin{array}{l}\text { Percentage } \\
\text { Score }\end{array}$ & Qualification & Information \\
\hline 1 & Farida Martarina & 100 & $100 \%$ & Very Good & $\begin{array}{l}\text { Worth Mass } \\
\text { Production, } \\
\text { Do not be revised }\end{array}$ \\
\hline 2 & $\begin{array}{l}\text { Iska Putranto } \\
\text { Ssaptadi, S.Pd }\end{array}$ & 98 & $98 \%$ & Very Good & $\begin{array}{l}\text { Worth Mass } \\
\text { Production, } \\
\text { Do not be revised }\end{array}$ \\
\hline 3 & $\begin{array}{l}\text { Drs. Frans Marie } \\
\text { Soepadi, M.M }\end{array}$ & 95 & $95 \%$ & Good & $\begin{array}{l}\text { Worth Mass } \\
\text { Production, } \\
\text { Do not be revised }\end{array}$ \\
\hline 4 & Mudah, S.Pd. M.Pd & 97 & $97 \%$ & Very Good & $\begin{array}{l}\text { Worth Mass } \\
\text { Production, } \\
\text { Do not be revised }\end{array}$ \\
\hline 5 & Boentoro BS. S.Pd & 98 & $98 \%$ & Very Good & $\begin{array}{l}\text { Worth Mass } \\
\text { Production, } \\
\text { Do not be revised }\end{array}$ \\
\hline 6 & Drs. Budi Haryono & 100 & $100 \%$ & Very Good & $\begin{array}{l}\text { Worth Mass } \\
\text { Production, } \\
\text { Do not be revised }\end{array}$ \\
\hline \multicolumn{2}{|c|}{ TOTAL AVERAGE } & 98 & $98 \%$ & Very Good & $\begin{array}{l}\text { Worth Testing, } \\
\text { Do not be revised }\end{array}$ \\
\hline
\end{tabular}

From table 5 above, we can see that the total score of the average validation of experts is $98 \%$ with very good qualifications and is suitable for mass production and does not need revision. It can be concluded that from the point of view of the six experts agree that the Bugar Card and Cinta Bugar Children Board are suitable for mass production.

Researchers believe that the success in implementing the modification of the Fit Five Special Olympics 2020 program cannot be separated from the role of the PJOK Teacher in working with parents. Both roles of parents are very important in assisting Down Syndrome children in doing fitness exercises at home given the limitations of Down Syndrome children.

This study aims to help PJOK teachers assist parents in maintaining the fitness of Down Syndrome children during the current large-scale social restrictions (PSBB) and in the future if there is another PSBB period, PJOK teachers and parents are no longer worried. In addition, this research can also train Down Syndrome children in their independence. Astuti \& Sukardi (2013) explain that there are 2 factors of independence, namely internal factors and external factors.

Astuti \& Sukardi (2013) also explain that internal factors come from within, namely genetics, age, birth order, intelligence and gender. If the external factor comes from the 
parenting style, the education system in the school and the condition of the surrounding community. In this case, internal factors are very influential on the development of children's independence.

From the research conducted, the sample felt happy, enthusiastic and able to perform fitness movements in accordance with the video direction, as well as the dangdut music remix contained in the video that made children with Down syndrome happy.

Next, the parents are very happy with the fitness card because it will remind them to assist their children in doing fitness exercises.

The products of fitness cards and the love board for children in fit are very helpful for PJOk teachers and parents in assisting with children with Down syndrome. And fit for mass production.

\section{Conclusion}

In the research results, we can see that the results of the recap validation of product trials by experts obtained a total average value of 98 with a percentage of $98 \%$ with very good qualifications. Likewise, the results of the recap of product trial validation by parents obtained a total average value of 98 with a percentage of $98 \%$ with very good qualifications. From the results of the recap of product trial validation by experts and parents, it can be concluded that:

1. Tools that can assist PJOK teachers and parents in assisting children with downsyndrome are the Bugar Card and the Fit Child Love Board.

2. The Bugar card falls into the "Very Good" category and is suitable for mass production.

3. The Cinta Anak Bugar Board falls into the "Very Good" category and is suitable for mass production.

4. Fitness videos fall into the "Excellent" category and deserve to be mass produced.

\section{References}

Abdurrahim, F., \& Hariadi, I. (2019). Tingkat Kebugaran Jasmani Siswa SDN Tulungrejo 03 Daerah Dataran Tinggi Kecamatan Bumiaji Kota Batu Tahun Pelajaran 2018/2019. Indonesia Performance Journal, 2 (1), 68-73.

Astuti, S., \& Sukardi, T. (2013). Faktor-faktor yang mempengaruhi kemandirian untuk berwirausaha pada siswa SMK. Jurnal Pendidikan Vokasi, 3(3), 334-346. https://oi.org/10.21831/jpv.v313.1847

C. Reotutar, M.A. (2020). Teacher Education Freshmen Applicants' Current State in the New Normal's Learning Delivery Platforms. Budapest International Research and Critics in Linguistics and Education (BirLE) Journal Vol 3 (3): 1528-1536.

Esposito,Phil. (2012). Physical Activity Patterns of Youth with Down Syndrome. Intellectual and Developmental Disabilities. Vol. 50, No. 2, 109-119.

Furqon, M. 2006. Mendidik Anak dengan Bermain. Surakarta: Fakultas Keguruan dan Ilmu Pendidikan Jurusan Pendidikan Olahraga dan Kesehatan Program Studi D-2 Pendidikan Jasmani.

García, P. L. R., Marcos, L. T., Guillamón, A. R., García-Cantó, E., Pérez-Soto, J. J., Casas, A. G., \& Lopez, P. T. (2014). Physical Fitness Level and Its Relationship with Self-Concept in School Children. Psychology, 05(18), 2009-2017. https://doi.org/10.4236/psych.2014.518204 
Gilmore, Linda A. and Campbell, Jennifer and Cuskelly, Monica (2003) Developmental Expectations, Personality Stereotypes, and Attitudes towards Inclusive Education: Community and Teacher Views of Down syndrome. International Journal of Disability, Development and Education 50 (1):pp. 65-76.

Gunarhadi. (2005). Penanganan Anak Down Syndrome Dalam Lingkungan Keluarga dan Sekolah. Jakarta. Direktorat Pembinaan Pendidikan Tenaga Kependidikan Dan Ketenagaan Perguruan Tinggi.

Joseph P. Kennedy Jr. Foundation. (2020). Fit 5 Guides. Sweden. Special Olympics

Komala. (2015). Mengenal dan Mengembangkan Kemandirian Anak Usia Dini Melalui Pola Asuh Orang Tua dan Guru. Tunas Siliwangi, 1(1), 31-45.

Maksum, Ali. (2018). Statistik Dalam Olahraga. Surabaya. Unesa University Press.

Marwa, I S. (2009). Pelaksanaan Bimbingan Dalam Menumbuhkan Kemandirian Anak Yang Mengalami Down Syndrome Di SLB-C Yayasan Lhrisna Murti Jakarta Selatan. Skripsi. Jurusan Bimbingan Dan penyuluhan Islam UIN Syarif Hidayatullah.

Pramudiana, I. D. (2017, Januari). Implementasi Kebijakan Pendidikan Inklusif Untuk Abk Di Surabaya. Jurnal Dimensi Pendidikan dan Pembelajaran, Volume 5 Nomor 1.

Sa'diyah, R. (2017). Pentingnya Melatih Kemandirian Anak. Jurnal KORDINAT, 16, 3146.

Sastaman, P. (2015). Berjalan Kaki dan Bersepda. Jurnal Pendidikan Olahraga, VOL. 4, No. 2, Desember 2015, 4(2), 170-181.

Satrio, M. W. (2014). Perbandingan Tingkat Kebugaran Jasmani Antara Siswa Bersepeda Dan Jalan Kaki Ke Sekolah ( Studi pada Siswa Kelas VIII SMP Negeri 2 Deket ) Endang Sri Wahjuni Abstrak. Jurnal Pendidikan Olahraga Dan Kesehatan, 2(1), 223-226.

Setyaningsih, P., \& Yuliandi, R. (2019). Perbandingan Tingkat Kebugaran Siswa yang Mengikuti dan Tidak Mengikuti Kegiatan Sanggar Tari. Ilmu Olah Raga Dan Kesehatan, 0(1), 1-8

Somatri, Sutjihati T. (2005). Psikologi Anak Luar Biasa. Bandng. PT. Refika Aditama.

Sriundy M. I Made. (2015). Metodologi Penelitian. Surabaya. Unesa University Press.

Sudjana, N. (2005). Penilaian Hasil Proses Belajar. Bandung: PT Remaja Rosdakarya

Suid, Syafrina, A., \& Tursinawati. (2017). Analisis Kemandirian Siswa Dalam Proses Pembelajaran Di Kelas Iii Sd Negeri 1 Banda Aceh. Jurnal Pesona Dasar, 1(1), 70-81.

Sugiharto (2020) Geographical students' learning outcomes on basic political science by using cooperative learning model with Group Investigation (GI) type in State University of Medan, Indonesia, Journal of Human Behavior in the Social Environment, 30:4, 447-456, DOI:10.1080/10911359.2019.1696261.

Sugiyono. (2019). Metode Penelitian \& Pengmbangan. Bandung. Alfabeta.

Wahid, R., Pribadi, F., and Wakas, B.E. (2020). Digital Activism: Covid-19 Effects in Campus Learning. Budapest International Research and Critics in Linguistics and Education (BirLE) Journal Vol 3 (3): 1336-1342. 